\title{
Sporadic idiopathic steroid-resistant nephrotic syndrome
}

INSERM

\section{Source}

INSERM. (1999). Orphanet: an online rare disease and orphan drug data base. Sporadic idiopathic steroid-resistant nephrotic syndrome. ORPHA:84271

Steroid-resistant, sporadic idiopathic nephrotic syndrome, is a heterogeneous entity. Nephrotic syndrome is characterised by marked proteinuria, with reduced plasmatic levels of albumin, and potentially with oedema. 